\title{
Preparation, Properties, and Microbial Impact of Tungsten (VI) Oxide and Zinc (II) Oxide Nanoparticles Enriched Polyethylene Sebacate Nanocomposites
}

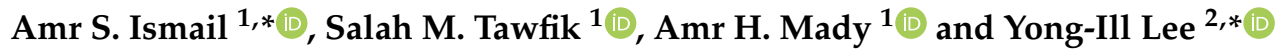 \\ 1 Petrochemicals Department, Egyptian Petroleum Research Institute (EPRI), Nasr City 11727, Cairo, Egypt; \\ salahtwfk85@yahoo.com (S.M.T.); amr_mady2005@yahoo.com (A.H.M.) \\ 2 Department of Chemistry, Changwon National University (CNU), Changwon 51140, Korea \\ * Correspondence: amrchems@gmail.com (A.S.I.); yilee@changwon.ac.kr (Y.-I.L.)
}

check for updates

Citation: Ismail, A.S.; Tawfik, S.M Mady, A.H.; Lee, Y.-I. Preparation, Properties, and Microbial Impact of Tungsten (VI) Oxide and Zinc (II) Oxide Nanoparticles Enriched Polyethylene Sebacate Nanocomposites. Polymers 2021, 13 718. https://doi.org/10.3390/ polym13050718

Academic Editor: Victor Tcherdyntsev

Received: 30 December 2020

Accepted: 22 February 2021

Published: 26 February 2021

Publisher's Note: MDPI stays neutra with regard to jurisdictional claims in published maps and institutional affiliations.

Copyright: (c) 2021 by the authors. Licensee MDPI, Basel, Switzerland. This article is an open access article distributed under the terms and conditions of the Creative Commons Attribution (CC BY) license (https:// creativecommons.org/licenses/by/ $4.0 /)$
Abstract: Nanoparticles of tungsten oxide $\left(\mathrm{WO}_{3}\right)$ and zinc oxide $(\mathrm{ZnO})$ enriched polyethylene sebacate (PES) nanocomposites were prepared through the coprecipitation process and condensation polymerization reaction. The obtained nano-sized particles of $\mathrm{WO}_{3}$ and $\mathrm{ZnO}, \mathrm{PES}$, and nanocomposites $\left(\mathrm{WO}_{3}\right.$-PES NC and ZnO-PES NC) were investigated. The average molecular weight of the cured PES was measured by employing the gel permeation chromatography (GPC) technique. Fourier-transform infrared spectroscopy (FTIR) and X-ray diffraction (XRD) spectra assured the formation of the polymeric nanocomposites. $\mathrm{WO}_{3}$ and $\mathrm{ZnO}$ nanoparticles supposed a condensed porous spherical phase found implanted in the polymer structure, as detected by scanning electron microscopy (SEM) and transmission electron microscopy (TEM) methods. These nano-scale systems achieved an electrical activity based on the conductive nanoparticles embedded matrix as a result of the ion-ion interactions. The microbial influence of the nanocomposites was examined against pathogenic bacteria; Pseudomonas aeruginosa, Escherichia coli, Staphylococcus aureus, and Bacillus subtilis, and Fungi; Aspergillus niger, and Candida albicans. Results exhibited that these nanocomposites have antimicrobial effects from moderate to slightly high on bacteria and high on fungi which was confirmed by a clear zone of inhibition. This study contributes to the design of reasonable composites to be under evaluation for their catalytic effect.

Keywords: polyester; metal oxide; nanocomposites; microbial activity; nanotechnology

\section{Introduction}

On the ever-accelerating progress of technology towards sustainable development, there are considerable research outputs in respect of the fabrication of eco-amiable nanosized material systems with formidable characteristics [1]. Recent advances and upcoming technologies are mainly focused on the overall coverage of the principles and methods concerning productions, properties, and implementations of nanomaterials [2,3]. By their distinguished properties, polymer-metal oxide composites have been widely investigated in recent years [4-8]. In this context, convenient processing procedures for fabricating metal oxides on elastic polymeric materials are highlighted. Metal oxides grafted semicrystalline and partially polymeric films such as polydimethylsiloxane (PDMS), polyethylene naphthalate (PEN), polyethylene terephthalate (PET), and polyimide (PI) have been studied $[9,10]$. Even though, a number of these amorphous polymeric films do not expose all the coveted characteristics regarding their morphology, stability, resistivity under ambient conditions [10]. Otherwise, soft composites based on linear aliphatic polyester (PE) are successfully employed to modify the polymer structure with new categories of strengthening components owing to their characteristics [11-15]. Predominately, positive reinforcement materials in nano-sized scales were embedded in the cast polymer composites to improve their physicochemical and electromechanical properties [16-19]. Metal oxides of Al, Ti, 
$\mathrm{Zr}$, and In with appropriate components are utilized in flexible devices based on their crystalline phases [20]. Compared to these oxide materials, nanoflakes, nanosheets, and nanowires of $\mathrm{WO}_{3}$ based polymeric composites were employed efficiently in various usages such as sensitive gas sensors [21,22], dye-sensitized solar cells [23], lithium-ion batteries [24], photochromic agents [25], photocatalytic and antibacterial agents [26,27], supercapacitors [28], water splitting [29,30], wastewater treatment [31], dye removal [32], smart windows [33], and anticancer agents [34]. As a result of the properties of zinc oxide, it has appeared a potential interest in the formulation of nano-sized polymeric systems [35]. Newly, the preparation of convenient components containing $\mathrm{ZnO}$ nanoparticles provides effective composites for several implementations such as acetone sensing [36], photocatalysis [37,38], photodegradation [39], microbial activity [40], cancer therapy [41], and wound dressing [42], food packaging [43] and water splitting [44]. Furthermore, the enhanced catalytic activity and promoted thermal-catalytic stability of $\mathrm{ZnO}$ nanostructures and its based hybrid materials under visible light effects were reported [45-48]. Consequently, the present research work endeavored to fabricate a polyester matrix composite of polyethylene sebacate enriched with nanocrystalline oxides of tungsten and zinc. These nano-oxides donate free electrons to the polymer matrix based on the difference in oxidation state. The sequential preparation of PES nanocomposites was achieved by condensation and deposition procedures. The composite systems were investigated. As well, the electrical conductivity and microbial performance of the obtained nanocomposites were examined.

\section{Experimental}

\subsection{Materials}

Experimental fabrication of polyethylene sebacate resin has been reported [49]. Sodium tungstate dehydrates, ferrous ammonium sulfate hexahydrate, zinc chloride hexahydrate, and cetyltrimethylammonium bromide were obtained from ADWIC (Qalyubia, Egypt), Sigma-Aldrich (Saint Louis, MO, USA) and Merck (Kenilworth, NJ, USA).

\subsection{Nano-Oxides Fabrication}

Sodium tungstate and ferrous ammonium sulfate (mole ratio 2:1) were dissolved in DW individually and mixed under sturdy stirring. A dark-colored suspension appeared which was dissolved by the addition of oxalic acid [50]. Eventually, a transparent colored solution was obtained with a $\mathrm{pH}$ value of 1 . The solution was shifted to a proper autoclaving system and aged for 2 days at $180^{\circ} \mathrm{C}$ to get the final product. Further, zinc oxide was prepared through the coprecipitation process in presence of CTAB [51]. CTAB based zinc chloride hexahydrate was dissolved in distilled water (mole ratio of 0.8), $2 \mathrm{M}$ aqueous $\mathrm{NaOH}$ medium was gradually added until $\mathrm{pH}$ raised to 11 . Then the mixture was stirred for $2 \mathrm{~h}$, shifted to autoclave, and aged for 2 days at $120^{\circ} \mathrm{C}$. After that centrifuged, washed, dried, and calcified for $4 \mathrm{~h}$ at $450{ }^{\circ} \mathrm{C}$. The obtained nanocrystalline oxides are described as $\mathrm{nWO}_{3}$ and $\mathrm{nZnO}$. The condensed porous crystalline phase was appeared with a particle size around $6-40 \mathrm{~nm}$ by using the Scherrer equation.

\subsection{Nanocomposite Fabrication}

Nanocomposites of $\mathrm{WO}_{3}$ and $\mathrm{ZnO}$ nanoparticles dispersed PES resin was fabricated throughout sequential proceedings as described in Figure 1. As an initial step, unbundling and dispersion of solid PES was operated by addition of about $10 \mathrm{~g}$ of resin to $50 \mathrm{~mL}$ of distilled water with sturdy stirring for $3 \mathrm{~h}$ at ambient temperature (Figure 1a). Thereafter, $0.05 \mathrm{~g}$ of nano-sized $\mathrm{WO}_{3}$ and $\mathrm{ZnO}$ as a solid powder was added quietly under vigorously stirring for $3 \mathrm{~h}$ (Wt.\% $0.05 \mathrm{MO}_{\mathrm{x}} / \mathrm{PES}$ ) [51]. Ultimately, the suspension was strongly stirred for $3 \mathrm{~h}$ and aged for $48 \mathrm{~h}$ at $100^{\circ} \mathrm{C}$ in a proper autoclaving system. Subsequently, the product was centrifuged, washed, and dried overnight. The yield was described as tungsten oxide and zinc oxide-based polyethylene sebacate nanocomposites $\left(\mathrm{WO}_{3}\right.$-PES NC) and ( $\mathrm{ZnO}-\mathrm{PES}$ NC) (Figure 1b,c). 


\section{(a)

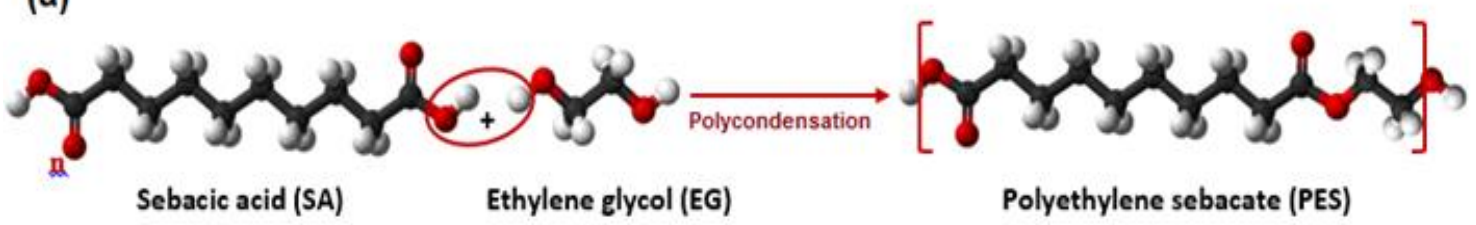

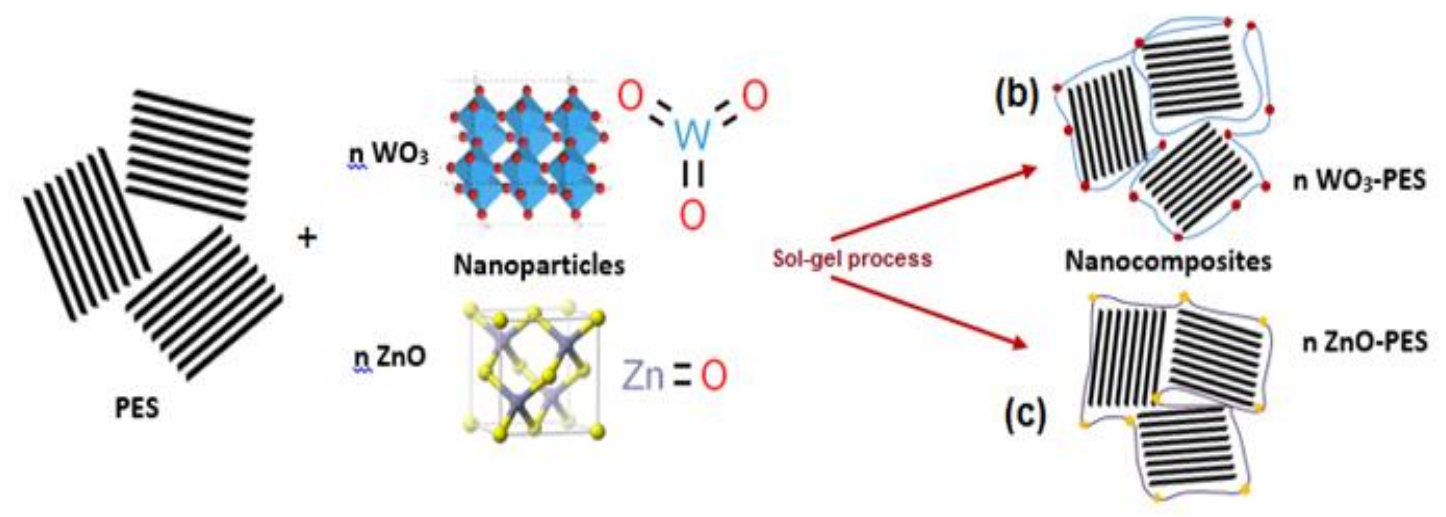

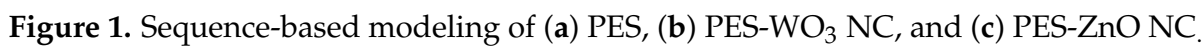

\subsection{Characterization Techniques}

Evaluation of weight throughout GPC analysis was performed by employing a Supremamax 3000 column at Polymer Standard Service with $2 \%$ acetic acid/0.2 M buffer sodium acetate as eluent $(1 \mathrm{~mL} / \mathrm{min})$. FTIR technique was performed by employing an ATI Mattson model Genesis Series (Fremont, CA, USA), infrared spectrophotometer adopting KBr technique. XRD analysis was performed by employing a Philips Powder Diffractometer and monochromatized $\mathrm{Cu} \mathrm{K} \alpha^{1}$ radiation in the range of $2 \theta=4-80^{\circ}$ at a potential of $40 \mathrm{KV}$ and a current value of $40 \mathrm{~mA}$ with a running step of $2^{\circ}$ in $2 \theta / \mathrm{min}$. SEM analysis was performed by employing a Jeol 5410 (Tokyo, Japan) instrument operated at a potential of $30 \mathrm{kV}$. TEM technique was performed by employing a Jeol instrument 2010 at a potential of $130 \mathrm{kV}$. The electrical activity was measured by using a Keithley test equipment-6517A Model-digit Electrometer (Solon, OH, USA). The microbial effect was examined by using the agar diffusion technique [52]. The tested composites were evaluated against Gram-positive bacteria (Bacillus subtilis ATCC 6633, Staphylococcus aureus ATCC 35556), Gram-negative bacteria (Escherichia coli ATCC 23282 and Pseudomonas aeruginosa ATCC 10145), Yeast (Candida albicans IMRU 3669), and Filamentous Fungus (Aspergillus niger ATCC 16404). The negative control was DMF showed no antimicrobial activity against the tested microorganisms, and the positive control was Erythromycin for bacteria and Metronidazole for yeast and fungus. All examinations were carried out in duplicates and the listed data are the average of the obtained results.

\section{Results and Discussion}

GPC values of the prepared PES were illustrated in detail in Table 1. Broadly, varied molecular weight measurements and determinations are detected owing to the step-growth melt polycondensation polymerization procedures. Under the extraordinary role of catalyst, a significant impact was exposed to molecular weight measurements of the polymer [53]. In the present work, the cured PES resin attained a total weight " $M_{n}$ " of 2103 , which takes into account all the polymeric molecules that exist. The attained mode "the highest peak" molecular weight distribution " $\mathrm{M}_{\mathrm{p}}$ " value was 2422 . Mass of the total polymeric chains " $\mathrm{M}_{\mathrm{w}}$ " value was 2621 . As well, the catalytic action diminished the glycol overtaking and accordingly minimized the whole period of the reaction. The PES reveals the crucial mechanism and kinetics of the catalytic esterification process [54]. 
Table 1. GPC of the prepared polyethylene sebacate (PES).

\begin{tabular}{cccccccc}
\hline No. & $\begin{array}{c}\text { Retention } \\
\text { Time }\end{array}$ & Mn & Mw & $\begin{array}{c}\text { MP } \\
\text { (Daltons) }\end{array}$ & $\begin{array}{c}\text { Mz } \\
\text { (Daltons) }\end{array}$ & $\begin{array}{c}\text { Mz + 1 } \\
\text { (Daltons) }\end{array}$ & $\begin{array}{c}\text { Poly- } \\
\text { Dispersity }\end{array}$ \\
\hline 1 & 28.883 & 2103 & 2621 & 2422 & 3240 & 3888 & 1.246 \\
\hline
\end{tabular}

FTIR spectra of PES, $\mathrm{WO}_{3}$-PES NC, and ZnO-PES NC are shown in Figure 2. From the obtained spectra patterns, soft broad absorption peaks for $\mathrm{OH}$ groups manifested at $3350 \mathrm{~cm}^{-1}$. Two common symmetric stretching bands for $\mathrm{CH}-$ and $\mathrm{CH}=$ were revealed at 2852 and $2917 \mathrm{~cm}^{-1}$. Associated with ester chain formation, strong and sharp spectra were present at $1739 \mathrm{~cm}^{-1}$. Moderate spectra are shown at $1465 \mathrm{~cm}^{-1}$ due to the methylene group. Functional $\mathrm{OH}$ bending appeared as a medium absorption at $1389 \mathrm{~cm}^{-1}$. Two bands at 1292 and $1217 \mathrm{~cm}^{-1}$ were due to $\mathrm{C}-\mathrm{O}$ of ester. $\mathrm{C}=\mathrm{C}$ bending of $\mathrm{CH}=$ was exposed as two peaks at 894 and $754 \mathrm{~cm}^{-1}$. Owing to the low content of nano-sized oxides in PES, there are no considerable distinctions among the diagrams in which the spectrometric techniques are mainly employed to detect the hydrocarbon components [54].

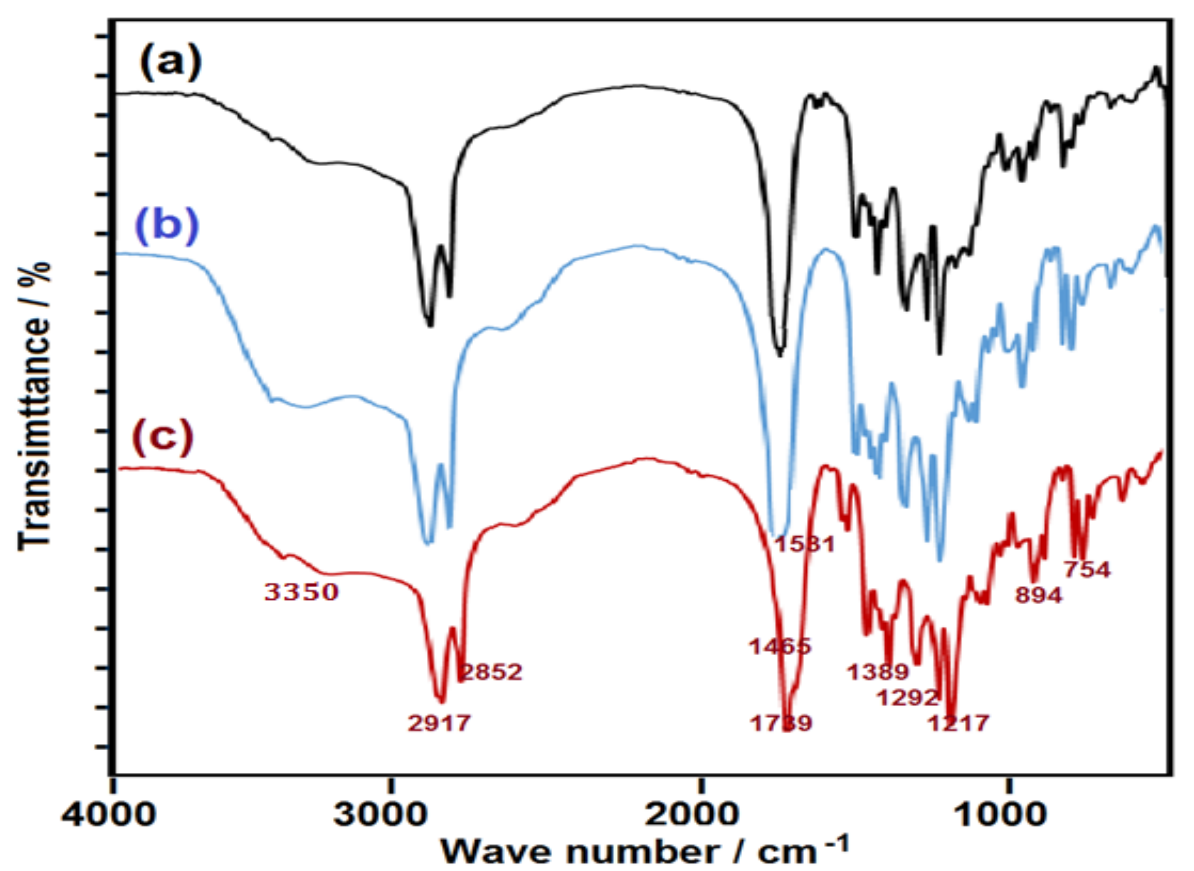

Figure 2. FTIR charts of (a) PES, (b) PES-WO $\mathrm{WO}_{3} \mathrm{NC}$, and (c) PES-ZnO NC composites.

XRD plots (Figure 3) for PES, $\mathrm{WO}_{3}$-PES NC, and $\mathrm{ZnO}-\mathrm{PES} \mathrm{NC}$ reveal the presence of multiple diffraction patterns observed. The reflections of the crystalline structure were recorded in the $2 \theta$ range of $6-45^{\circ}$. The characteristic crystalline peaks appeared at around $2 \theta=6.06^{\circ}(30.4 \%), 21.75^{\circ}(100 \%)$, and $24.64^{\circ}(57.12 \%)$. The exposed value at $2 \theta=21.75^{\circ}$ is correlated to the high content of the ester series. Medium appearance at $2 \theta=6.06^{\circ}$ was due to rough form. The PES backbone contains prolonged polymer chains referring to various arrangements of polyester bindings [55]. ASTM 24-1148 and ASTM 89-0598 were reported in the diffraction plots of $\mathrm{WO}_{3}$ and $\mathrm{ZnO}$. Otherwise, the characteristic strong and

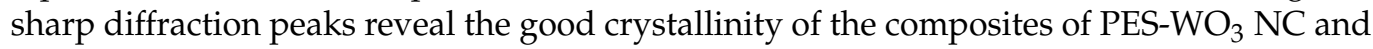
PES-ZnO NC. The characteristic peaks at $2 \theta=6.0^{\circ}, 13.4^{\circ}, 20.4^{\circ}, 21.7^{\circ}, 24.5^{\circ}, 29.8^{\circ}, 30.6^{\circ}$, $38.8^{\circ}$, and $41.5^{\circ}$ are related to the (020), (120), (032), (131), and (220) patterns of PES (JPDS: 04-0783). The high intensity and narrow peaks are detected at $2 \theta=6.0^{\circ}, 7.2^{\circ}, 21.7^{\circ}, 21.9^{\circ}$, $24.6^{\circ}, 24.7^{\circ}, 30.6^{\circ}, 38.8^{\circ}, 41.7^{\circ}$, and $45.4^{\circ}$ are correlated to the (020), (020), (200), (120), (111), (120), (131), (200), (202), and (222) crystalline planes of the spherical phase of $\mathrm{WO}_{3}$ (JPDS: 43-0679). The strongest diffraction peaks observed at $2 \theta$ values of $5.9^{\circ}, 8.0^{\circ}, 11.4^{\circ}, 17.3^{\circ}$, 
$20.2^{\circ}, 21.6^{\circ}, 24.5^{\circ} 30.3^{\circ}, 35.8^{\circ}, 38.7^{\circ}$, and $41.2^{\circ}$ corresponding to the planes (020), (120), (101), (100), (131), (002), (101), and (110) of ZnO (JPDS: 36-1451). The size of crystals was measured using the Scherrer equation to the peaks at $2 \theta=24.64^{\circ}$ and $2 \theta=21.75^{\circ}$ around 36 and $16 \mathrm{~nm}$.

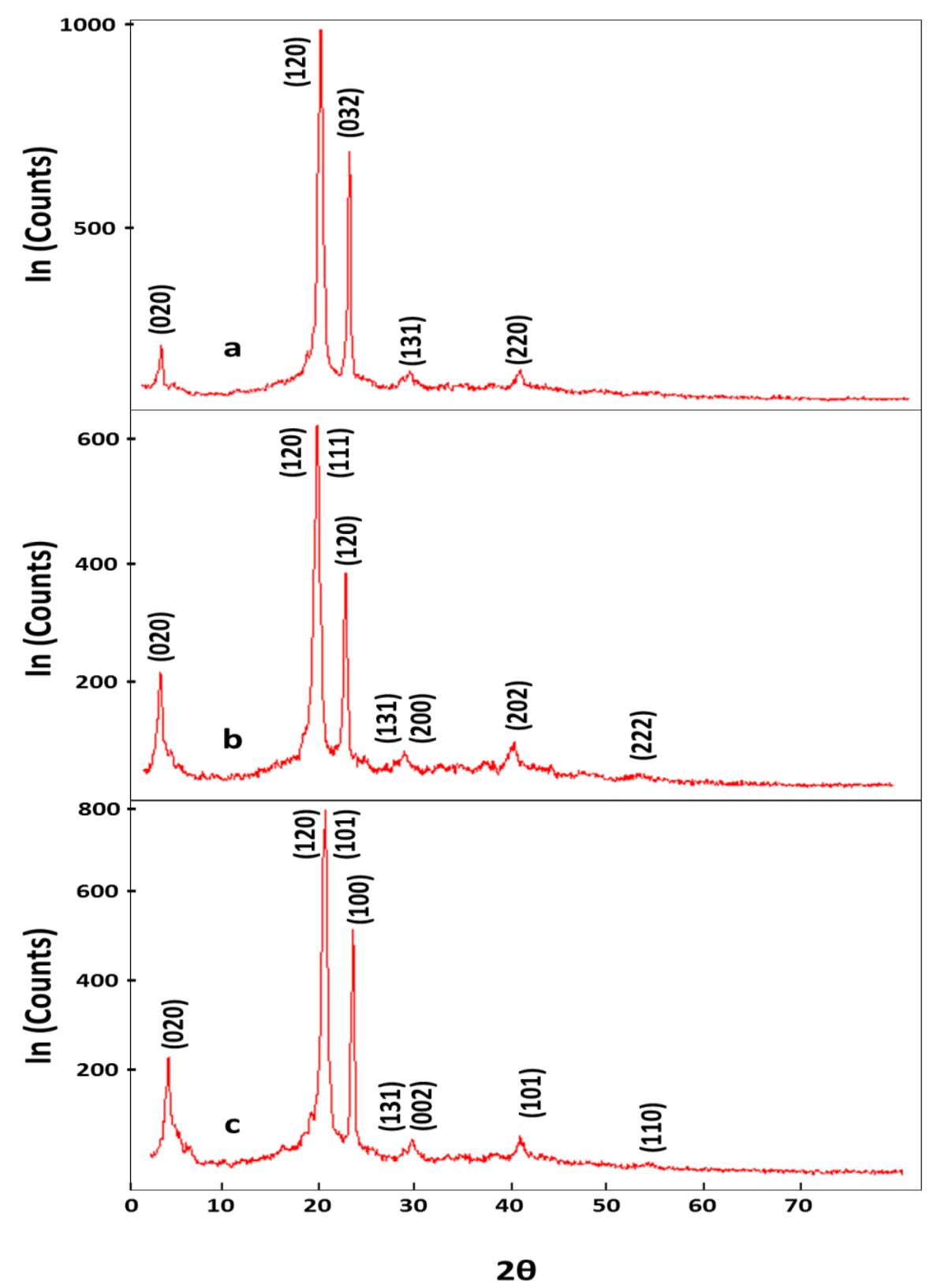

Figure 3. XRD charts of (a) PES, (b) PES-WO $\mathrm{WO}_{3} \mathrm{NC}$, and (c) PES-ZnO NC composites.

The surface morphology of metal oxide nanoparticles was characterized using the SEM technique. Before the discussion, metal oxides were found to be granulated particles. The agglomeration performance is mostly similar to all metal oxide particles prepared at relatively low temperatures [56]. With the elevating temperatures, the highly agglomerated crystalline domains were found to have fused spherical-shaped nanoparticles as shown in Figure 4. In the case of nanoparticles-based polymer ( $\mathrm{WO}_{3}$-PES NC and ZnO-PES NC), SEM images (Figure 5) were found to have condensed porous shape for $\mathrm{WO}_{3}$-PES NC (Figure 5a) and diverged rode shape for ZnO-PES NC (Figure 5b). 

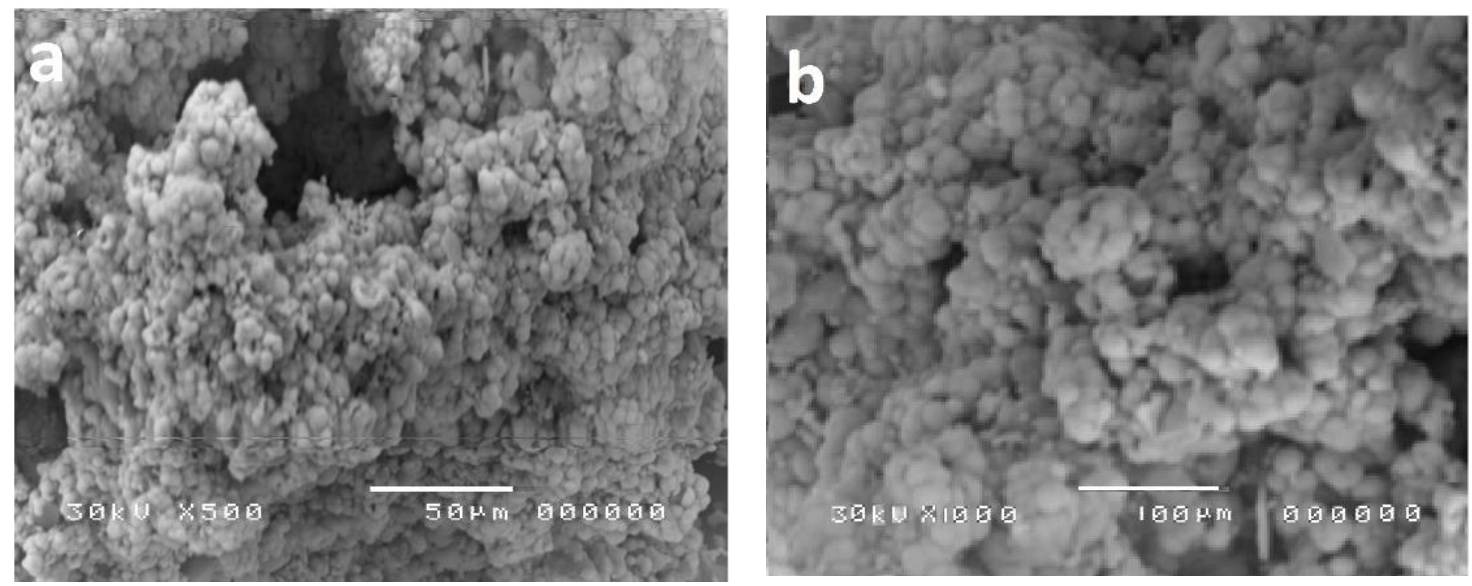

Figure 4. SEM graphs of the selected metal oxide nanoparticles $\left(\mathrm{nMOx}=(\mathbf{a}) \mathrm{WO}_{3} /(\mathbf{b}) \mathrm{ZnO}\right)$
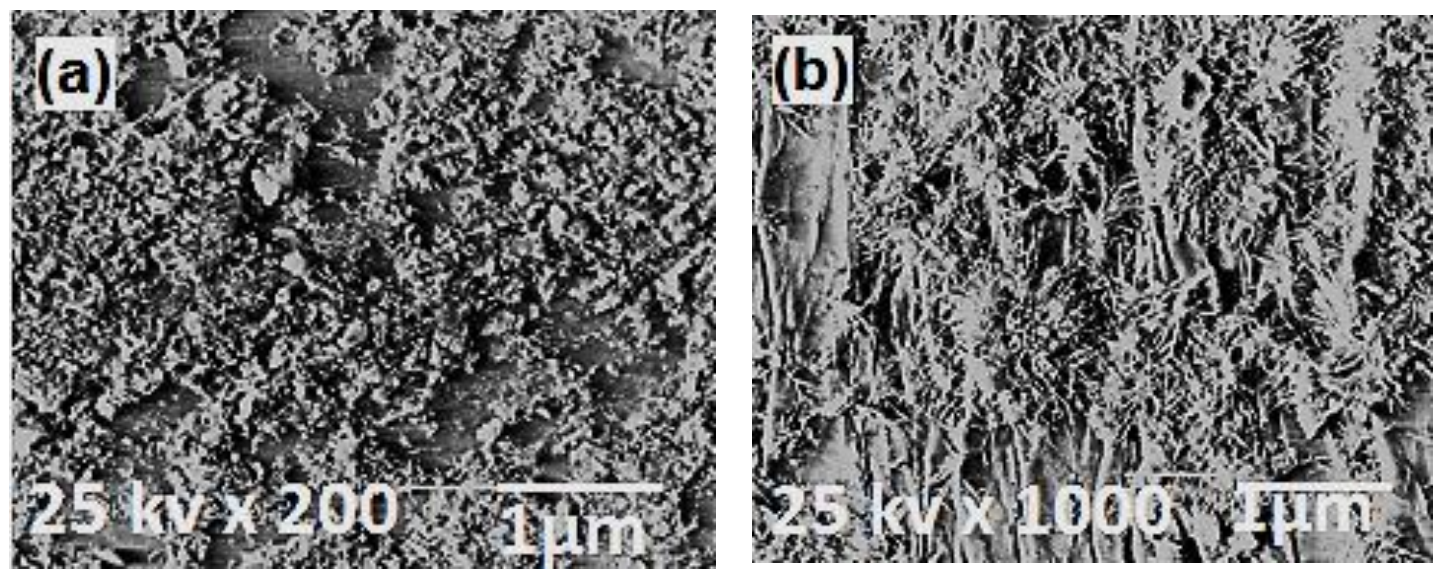

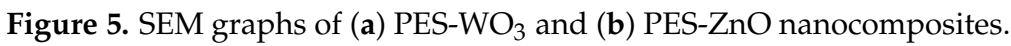

TEM micrographs of nano-sized oxides and polymer nanocomposites were studied. Regarding this issue, some micrographs of their polymeric structure and dispersed metallic particles are exhibited. As images display, pure nanoparticles were spherical flaked and randomly distributed in several areas, whereas particle agglomerates still existed and remained almost free areas (Figure 6).

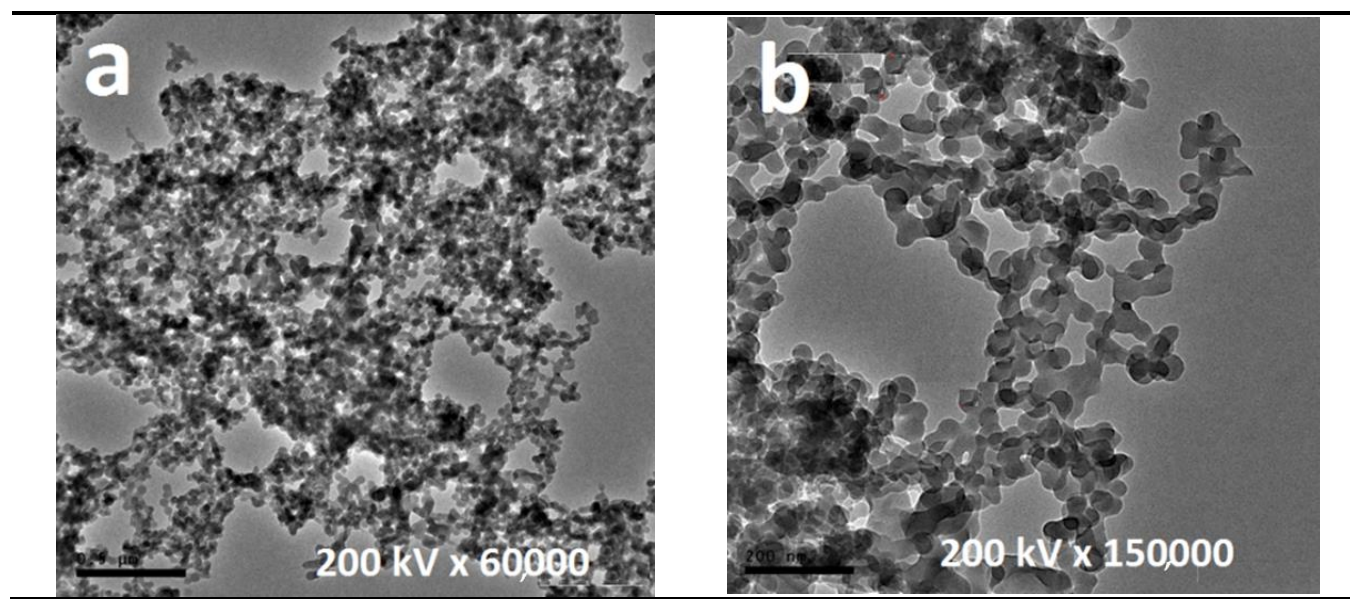

Figure 6. TEM graphs of the selected metal oxide nanoparticles $\left(\mathrm{nMO}_{\mathrm{x}}=(\mathbf{a}) \mathrm{WO}_{3} /(\mathbf{b}) \mathrm{ZnO}\right)$. 
In general, the electrical conductivity of the polymeric composites can be promoted by adding a conductive nanomaterial into the polymer phase. The enhancement performance is owing to the formation of a permanent conductive network along with the polymer structure. The electrical conductivity values of polymer materials containing conductive nanofillers depend on nanophase content, dispersion area, temperature, and the particle size of the nanocomposites [57]. The electrical conductivity of PES, $\mathrm{WO}_{3}-\mathrm{PES} \mathrm{NC}$, and $\mathrm{ZnO}-\mathrm{PES} \mathrm{NC}$ is displayed in Figure 7. From the graphs, conductivity measurements progressively increased by increasing temperature. This action corresponds with the typical ionization performance of functional $\mathrm{COOH}$ in the polyester matrix. High conductivities are correlated to the nano solids and heat effects [58].

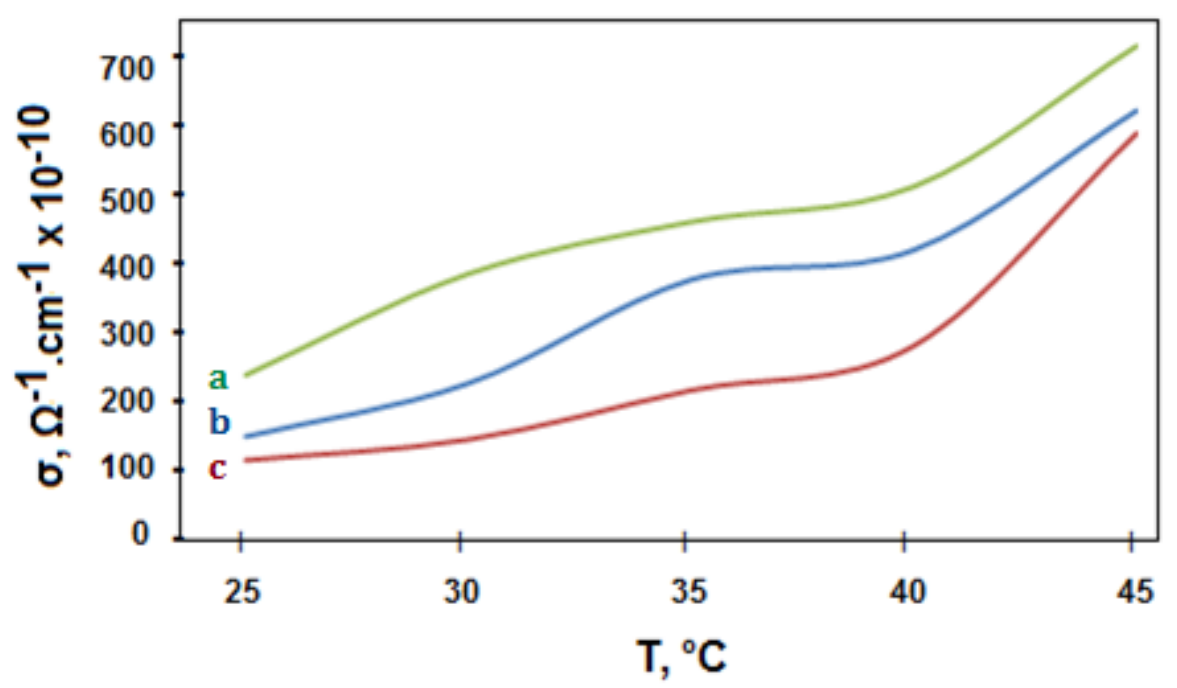

Figure 7. Conductivity diagram of (a) PES-ZnO, (b) PES, (c) PES-WO $\mathrm{WO}_{3}$ systems.

The microbial impacts of PES and its nanocomposites were evaluated against pathogenic Gram-negative bacteria, (Pseudomonas aeruginosa ATCC 10145 and Escherichia coli ATCC 23282), Gram-positive bacteria (Staphylococcus aureus ATCC 35556 and Bacillus subtilis ATCC 6633), and fungi (Aspergillus niger ATCC 16404 and Candida albicans IMRU 3669 ) at a concentration of $5 \mathrm{mg} / \mathrm{mL}$. The bacteria and yeast were grown on nutrient agar while the fungus was grown on Czapek's Dox agar medium. Data in Table 2 indicate that the obtained composites' antimicrobial effects range from moderate to slightly high on Gram-negative bacteria and from slightly high to high on Gram-positive bacteria and very high effect on fungi compared to the drug reference used. The values of the inhibition zones indicate the cytotoxic efficacy of these compounds against the studied fungi. The inhibition diameter values showed that the cytotoxic efficacies of these compounds are strongly related to their surface properties and the type of transition metal. The bactericidal effect of metal nanocomposite has been assigned to their small size and high surface to volume ratio, which allows them to interact closely with microbial membranes and is not solely owing to the release of metal ions in the medium. A cell wall exists around the outside of the microorganism cell membrane and it is essential to the survival of bacteria. Such a phenomenon can be explained based on Overtone's concept and chelation theory [59-61]. 
Table 2. Antimicrobial activity of PES, PES- $\mathrm{WO}_{3}$, and PES-ZnO, measured by (mm).

\begin{tabular}{ccccccc}
\hline Test Organism & \multicolumn{2}{c}{ (+ve) Bacteria } & \multicolumn{2}{c}{ (-ve) Bacteria } & \multicolumn{2}{c}{ Fungi } \\
\cline { 2 - 6 } Compound ID & $\begin{array}{c}\text { Bacillus } \\
\text { subtilis }\end{array}$ & $\begin{array}{c}\text { Staph. } \\
\text { aureus }\end{array}$ & $\begin{array}{c}\text { Escherichia } \\
\text { coli }\end{array}$ & $\begin{array}{c}\text { Pseud. } \\
\text { aeruginosa }\end{array}$ & $\begin{array}{c}\text { Candida } \\
\text { albicans }\end{array}$ & $\begin{array}{c}\text { Aspergillus } \\
\text { niger }\end{array}$ \\
\hline PES & 13 & 18 & 12 & 12 & 28 & 25 \\
PES-WO3 & 13 & 16 & 13 & 13 & 17 & 19 \\
PES-ZnO & 12 & 17 & 13 & 12 & 20 & 28 \\
Reference & 32 & 34 & 32 & 33 & 26 \\
\hline
\end{tabular}

\section{Conclusions}

The current study presents the preparation of $\mathrm{WO}_{3}$ and $\mathrm{ZnO}$ nanoparticles dispersed PES nanocomposites through the precipitation process and esterification reaction. Mass, structure, composition, morphology, conductivity, and microbial activity of the obtained systems were evaluated. Spectra of FTIR and XRD techniques confirmed the fabrication of polymer nanocomposites. It reveals the existence of several patterns for PES composites. The grain size of $\mathrm{WO}_{3}$ and $\mathrm{ZnO}$ were found in the nano-crystalline regime. SEM and TEM images show condensed spherical shaped nanomaterials embedded in the PES lattice. The nanocomposites based on $\mathrm{nWO}_{3}$ and $\mathrm{nZnO}$ exposed an electrical conductivity effect due to the interaction of ions in which the values are increased under heat. The antimicrobial results revealed a moderate effect on bacteria and a high effect on fungi for the nanocomposites based on inhibition zone. As a result, the current research contributes to the fabrication of reasonable nanomaterials to be under evaluation for their catalytic activity.

Author Contributions: A.S.I.: Conceptualization, Data curation, Formal analysis, Methodology, Investigation, Writing, Writing-review and Editing; S.M.T.: Formal analysis, Data curation, Investigation, Writing; A.H.M.: Formal analysis, Data curation, Investigation, Writing; Y.-I.L.: Funding acquisition, Project administration, Writing-review and Editing. All authors have read and agreed to the published version of the manuscript.

Funding: This research was funded by the Korean government (MSIT) (No. 2020R1A2C2007028)

Data Availability Statement: Not applicable.

Acknowledgments: The authors gratefully acknowledge the support of the Egyptian Petroleum Research Institute (EPRI) and the National Research Foundation of Korea (NRF).

Conflicts of Interest: The authors declare no conflict of interest.

\section{References}

1. Gupta, C.; Bhardwaj, A. Summary and future perspectives of nanomaterials and technologies: Special emphasis on energy and environment. In Nanomaterials for Sustainable Energy and Environmental Remediation; Elsevier: Amsterdam, The Netherlands, 2020; pp. 333-353.

2. Pathakoti, K.; Manubolu, M.; Hwang, H.-M. Nanotechnology applications for environmental industry. In Handbook of Nano Materials for Industrial Applications; Elsevier: Amsterdam, The Netherlands, 2018; p. 894.

3. Dong, P.; Prasanth, R.; Xu, F.; Wang, X.; Li, B.; Shankar, R. Eco-friendly polymer nanocomposite-properties and processing. In Eco-Friendly Polymer Nanocomposites; Thakur, V., Thakur, M., Eds.; Springer: New Delhi, India, 2015; Volume 75, p. 1.

4. Boyaciyan, D.; von Klitzing, R. Stimuli-responsive polymer/metal composites: From fundamental research to self-regulating devices. Curr. Opin. Colloid Interface Sci. 2019, 44, 193-207. [CrossRef]

5. Jimmy, J.; Kandasubramanian, B. MXene functionalized polymer composites: Synthesis and applications. Eur. Polym. J. 2020, 122, 109367. [CrossRef]

6. Biswal, T.; BadJena, S.K.; Pradhan, D. Synthesis of polymer composite materials and their biomedical applications. Mater. Today Proc. 2020, 30, 305-315. [CrossRef]

7. Rawat, M.K.; Kukreja, N.; Gupta, S.K. Effect of reinforcing micro sized aluminium oxide particles on mechanical properties of polymer based composite. Mater Today Proc. 2020, 26, 1306-1309. [CrossRef]

8. Tiwari, V.K.; Song, H.; Oh, Y.; Jeong, Y. Synthesis of sulfur-co-polymer/porous long carbon nanotubes composite cathode by chemical and physical binding for high performance lithium-sulfur batteries. Energy 2020, 195, 117034. [CrossRef]

9. Wooh, S.; Encinas, N.; Vollmer, D.; Butt, H.-J. Stable hydrophobic metal-oxide photocatalysts via grafting polydimethylsiloxane brush. Adv. Mater. 2017, 29, 1604637. [CrossRef] [PubMed] 
10. With, P.C.; Helmstedt, U.; Prager, L. Flexible transparent barrier applications of oxide thin films prepared by photochemical conversion at low temperature and ambient pressure. Front. Mater. 2020, 7, 1-13. [CrossRef]

11. Neves, A.C.C.; Rohen, L.A.; Mantovani, D.P.; Carvalho, J.P.R.G.; Vieira, C.M.F.; Lopes, F.P.D.; Monteiro, S.N. Comparative mechanical properties between biocomposites of epoxy and polyester matrices reinforced by hemp fiber. J. Mater. Res. Technol. 2019, 9, 1296-1304. [CrossRef]

12. Rajesh, G.; Revuri, A.; Arekapudi, M.S.; DBM, G.R. Evaluating tensile properties of phragmites karka fibre reinforced polyester composites. Mater. Today Proc. 2019, 18, 8-14. [CrossRef]

13. Ezahra, T.F.; Abderrahmane, E.I.; Reda, B.; Abdeslam, A.; Mohamed, A.; Soufian, E.B.; Abdesselam, T. Cellulose grafted aliphatic polyesters: Synthesis, characterization and biodegradation under controlled conditions in a laboratory test system. J. Mol. Struct. 2019, 1205, 127582.

14. Li, S.; Liu, Z.; Hou, L.; Chen, Y.; Xu, T. Effect of polyether/polyester polyol ratio on properties of waterborne two-component polyurethane coatings. Prog. Org. Coat. 2020, 141, 105545. [CrossRef]

15. Ismail, A.S. Interactive effect of ethylene diamine in preparation of chitosan-based poly(ester-urethane) elastomers. Int. J. Sci. Eng. Technol. 2015, 3, 1340-1343.

16. Verma, D.K.; Purohit, R.; Rana, R.S.; Purohit, S.; Patel, K.K. Enhancement of the properties of shape memory polymers using different nano size reinforcement-A review. Mater. Today Proc. 2020, 26, 3037-3042. [CrossRef]

17. Kartik Shubham, S.; Purohit, R.; Yadav, P.S.; Rana, R.S. Study of nano-fillers embedded in polymer matrix composites to enhance its properties-A review. Mater. Today Proc. 2020, 26, 3024-3029. [CrossRef]

18. Guo, W.; Xu, L.; Feng, P.; Gu, Y.; Shuai, C. In-situ growth of silica nano-protrusions on halloysite nanotubes for interfacial reinforcement in polymer/halloysite scaffolds. Appl. Surf. Sci. 2020, 513, 145772. [CrossRef]

19. Han, T.; Nagarajan, S.; Zhao, H.; Sun, C.; Wen, S.; Zhao, S.; Zhang, L. Novel reinforcement behavior in nanofilled natural rubber (NR) / butadiene-acrylonitrile rubber (NBR) blends: Filling-polymer network and supernanosphere. Polymer 2019, 186, 122005. [CrossRef]

20. Jeong, J.W.; Hwang, H.S.; Choi, D.; Ma, B.C.; Jung, J.; Chang, M. Hybrid polymer/metal oxide thin films for high performance, flexible transistors. Micromachines 2020, 11, 264. [CrossRef] [PubMed]

21. Hung, C.M.; Dat, D.Q.; Van Duy, N.; Van Quang, V.; Van Toan, N.; Van Hieu, N.; Hoa, N.D. Facile synthesis of ultrafine rGO/WO 3 nanowire nanocomposites for highly sensitive toxic $\mathrm{NH}_{3}$ gas sensors. Mater. Res. Bull. 2020, 125, 110810. [CrossRef]

22. Wang, C.; Zhang, S.; Qiu, L.; Rasaki, S.A.; Qu, F.; Thomas, T.; Yang, M. Ru-decorated $\mathrm{WO}_{3}$ nanosheets for efficient xylene gas sensing application. J. Alloys Compd. 2020, 826, 154196. [CrossRef]

23. Younas, M.; Gondal, M.A.; Dastageer, M.A.; Baig, U. Fabrication of cost effective and efficient dye sensitized solar cells with $\mathrm{WO}_{3}-\mathrm{TiO}_{2}$ nanocomposites as photoanode and MWCNT as Pt-free counter electrode. Ceram. Int. 2018, 45, 936-947. [CrossRef]

24. Kim, H.; Ryu, J.H.; Kim, J.; Hwang, K.; Kang, H.; Oh, S.M.; Yoon, S. Ordered mesoporous tungsten oxide-carbon nanocomposite for use as a highly reversible negative electrode in lithium-ion batteries. J. Alloys Compd. 2020, 832, 154816. [CrossRef]

25. Oderinde, O.; Hussain, I.; Kang, M.; Wu, Y.; Mulenga, K.; Adebayo, I.; Fu, G. Water as DES-cosolvent on the morphology tuning and photochromic enhancement of tungsten oxide-molybdenum oxide nanocomposite. J. Ind. Eng. Chem. 2019, 80, 1-10. [CrossRef]

26. Jeevitha, G.; Abhinayaa, R.; Mangalaraj, D.; Ponpandian, N. Tungsten oxide-graphene oxide $\left(\mathrm{WO}_{3}-\mathrm{GO}\right)$ nanocomposite as an efficient photocatalyst, antibacterial and anticancer agent. J. Phys. Chem. Solids 2018, 116, 137-147. [CrossRef]

27. Renukadevi, R.; Sundaram, R. Synthesis, characterization, humidity sensing, antibacterial, photocatalytic and kinetic studies of novel $\mathrm{HgWO}_{4}-\mathrm{WO}_{3}$ nanocomposites. Mater. Today Proc. 2019, 8, 153-161. [CrossRef]

28. Pawar, S.M.; Pawar, B.S.; Babar, P.T.; Ahmed, A.T.A.; Chavan, H.S.; Jo, Y.; Cho, S.; Kim, J.; Hou, B.; Inamdar, A.I.; et al. Nanoporous $\mathrm{CuCo}_{2} \mathrm{O}_{4}$ nanosheets as a highly efficient bifunctional electrode for supercapacitors and water oxidation catalysis. Appl. Surf. Sci. 2019, 470, 360-367. [CrossRef]

29. Hosseini, M.G.; Yardani Sefidi, P.; Musap Mert, A.; Kinayyigit, S. Investigation of solar-induced photoelectrochemical water splitting and photocatalytic dye removal activities of camphor sulfonic acid doped polyaniline- $\mathrm{WO}_{3}-\mathrm{MWCNT}$ ternary nanocomposite. J. Mater. Sci. Technol. 2019, 38, 7-18. [CrossRef]

30. Sekar, S.; Talha Aqueel Ahmed, A.; Pawar, S.M.; Lee, Y.; Im, H.; Young Kim, D.; Lee, S. Enhanced water splitting performance of biomass activated carbon-anchored $\mathrm{WO}_{3}$ nanoflakes. Appl. Surf. Sci. 2019, 508, 145127. [CrossRef]

31. Beyhaqi, A.; Zeng, Q.; Chang, S.; Wang, M.; Taghi Azimi, S.M.; Hu, C. Construction of g- $\mathrm{C}_{3} \mathrm{~N}_{4} / \mathrm{WO}_{3} / \mathrm{MoS}_{2}$ ternary nanocomposite with enhanced charge separation and collection for efficient wastewater treatment under visible light. Chemosphere 2020, 247, 125784. [CrossRef]

32. Tijani, J.O.; Ugochukwu, O.; Fadipe, L.A.; Bankole, M.T.; Abdulkareem, A.S.; Roos, W.D. Photocatalytic degradation of local dyeing wastewater by iodine-phosphorus co-doped tungsten trioxide nanocomposites under natural sunlight irradiation. J. Environ. Manag. 2019, 236, 519-533. [CrossRef] [PubMed]

33. Zargoosh, K.; Moradi Aliabadi, $\mathrm{H} . \mathrm{SrAl}_{2} \mathrm{O}_{4}: \mathrm{Eu}^{2+}$ : $\mathrm{Dy}^{3+} / \mathrm{WO}_{3} /$ polyester nanocomposite as a highly efficient and environmentally friendly photocatalyst for removal of dyes from industrial wastes. Environ. Nanotechnol. Monit. 2019, 12, 100273. [CrossRef]

34. Zhao, Q.; Fang, Y.; Qiao, K.; Wei, W.; Yao, Y.; Gao, Y. Printing of $\mathrm{WO}_{3} / \mathrm{ITO}$ nanocomposite electrochromic smart windows. Sol. Energy Mater. Sol. Cells 2019, 194, 95-102. [CrossRef] 
35. Devaraju, A.; Sivasamy, P.; Loganathan, G.B. Mechanical properties of polymer composites with ZnO nano-particle. Mater. Today Proc. 2019, 22, 531-534. [CrossRef]

36. Yin, M.; Wang, Y.; Liu, S. Synthesis of $\mathrm{Fe}_{2} \mathrm{O}_{3}-\mathrm{ZnWO}_{4}$ nanocomposites and their enhanced acetone sensing performance. J. Alloys Compd. 2020, 831, 154713. [CrossRef]

37. Habib, M.A.; Shahadat, M.T.; Bahadur, N.M.; Ismail, I.M.; Mahmood, A. Synthesis and characterization of $\mathrm{ZnO}-\mathrm{TiO}_{2}$ nanocomposites and their application as photocatalysts. Int. Nano Lett. 2013, 3, 1-8. [CrossRef]

38. Ramezani Darabi, R.; Jahanshahi, M.; Peyravi, M. A support assisted by photocatalytic $\mathrm{Fe}_{3} \mathrm{O}_{4} / \mathrm{ZnO}$ nanocomposite for thin-film forward osmosis membrane. Chem. Eng. Res. Des. 2018, 133, 11-25. [CrossRef]

39. Zhang, Y.; Xu, J.; Guo, B. Photodegradation behavior of poly(butylene succinate-co-butylene adipate)/ZnO nanocomposites. Colloids Surf. A Physicochem. Eng. Asp. 2016, 489, 173-181. [CrossRef]

40. Amani, A.; Montazer, M.; Mahmoudirad, M. Synthesis of applicable hydrogel corn silk/ZnO nanocomposites on polyester fabric with antimicrobial properties and low cytotoxicity. Int. J. Biol. Macromol. 2018, 123, 1079-1090. [CrossRef] [PubMed]

41. Vasuki, K.; Manimekalai, R. NIR light active ternary modified ZnO nanocomposites for combined cancer therapy. Heliyon 2019, 5, e02729. [CrossRef]

42. Bužarovska, A.; Dinescu, S.; Lazar, A.D.; Serban, M.; Pircalabioru, G.G.; Costache, M.; Avérous, L. Nanocomposite foams based on flexible biobased thermoplastic polyurethane and $\mathrm{ZnO}$ nanoparticles as potential wound dressing materials. Mater. Sci. Eng. C 2019, 104, 109893. [CrossRef]

43. El Fawal, G.; Hong, H.; Song, X.; Wu, J.; Sun, M.; He, C.; Wang, H. Fabrication of antimicrobial films based on hydroxylethylcellulose and $\mathrm{ZnO}$ for food packaging application. Food Packag. Shelf Life 2020, 23, 100462. [CrossRef]

44. Sreedhar, A.; Reddy, I.N.; Hoai Ta, Q.T.; Namgung, G.; Cho, E.; Noh, J.-S. Facile growth of novel morphology correlated $\mathrm{Ag} / \mathrm{Co}-$ doped $\mathrm{ZnO}$ nanowire/flake-like composites for superior photoelectrochemical water splitting activity. Ceram. Int. 2019, 45, 6985-6993. [CrossRef]

45. Liu, X.; Chen, C. Mxene enhanced the photocatalytic activity of ZnO nanorods under visible light. Mater. Lett. 2020, $261,127127$. [CrossRef]

46. Chen, C.; Mei, W.; Wang, C.; Yang, Z.; Chen, X.; Chen, X.; Liu, T. Synthesis of a flower-like SnO/ZnO nanostructure with high catalytic activity and stability under natural sunlight. J. Alloys Compd. 2020, 826, 154122. [CrossRef]

47. Yulizar, Y.; Apriandanu, D.O.B.; Ashna, R.I. $\mathrm{La}_{2} \mathrm{CuO}_{4}$-decorated $\mathrm{ZnO}$ nanoparticles with improved photocatalytic activity for malachite green degradation. Chem. Phys. Lett. 2020, 755, 137749. [CrossRef]

48. Dedova, T.; Acik, I.O.; Chen, Z.; Katerski, A.; Balmassov, K.; Gromyko, I.; Nagyne-Kovacs, T.; Szilagyi, I.M.; Krunks, M. Enhanced photocatalytic activity of $\mathrm{ZnO}$ nanorods by surface treatment with $\mathrm{HAuCl}_{4}$ : Synergic effects through an electron scavenging, plasmon resonance and surface hydroxylation. Mater. Chem. Phys. 2020, 245, 122767. [CrossRef]

49. Ismail, A.S.; Mady, A.H.; Tawfik, S.M. Synthesis, characterization and biological activity of iron (III) oxide and titanium (IV) oxide nanoparticle dispersed polyester resin nanocomposites. Arab. J. Sci. Eng. 2019, 45, 197-203. [CrossRef]

50. Corrie, C.L.; Klabunde, K.J. The catalytic methanol synthesis over nanoparticle metal oxide catalysts. J. Mol. Catal. A Chem. 2003, 194, 227-237.

51. Hoseini, F.; Farahamndjou, M.; Firoozabadi, T.P. Coprecipitation synthesis of zinc ferrit $\left(\mathrm{Fe}_{2} \mathrm{O}_{3} / \mathrm{ZnO}\right)$ nanoparticles prepared by CTAB surfactant. J. Fundam. Appl. Sci. 2016, 8, 738-745. [CrossRef]

52. Lu, G.; Wu, D.; Fu, R. Studies on the synthesis and antibacterial activities of polymeric quaternary ammonium salts from dimethylaminoethyl methacrylate. React. Funct. Polym. 2007, 67, 355-366. [CrossRef]

53. Terzopoulou, Z.; Karakatsianopoulou, E.; Kasmi, N.; Tsanaktsis, V.; Nikolaidis, N.; Kostoglou, M.; Bikiaris, D.N. Effect of catalyst type on molecular weight increase and coloration of poly(ethylene furanoate) biobased polyester during melt polycondensation. Polym. Chem. 2017, 8, 6895-6908. [CrossRef]

54. Ni, Z.; Li, F.; Wang, H.; Wang, S.; Gao, S. Catalytic esterification, kinetics, and cold flow properties of isobutyl palmitate. Fuel 2019, 254, 115368. [CrossRef]

55. Zia, K.M.; Zuber, M.; Barikani, M.; Jabbar, A.; Khosa, M.K. XRD pattern of chitin based polyurethane bio-nanocomposites. Carbohydr. Polym. 2010, 80, 539-543. [CrossRef]

56. Nagarjuna, R.; Challagulla, S.; Sahu, P.; Roy, S.; Ganesan, R. Polymerizable sol-gel synthesis of nano-crystalline $\mathrm{WO}_{3}$ and its photocatalytic $\mathrm{Cr}(\mathrm{VI})$ reduction under visible light. Adv. Powder Technol. 2017, 28, 3265-3273. [CrossRef]

57. Cerisuelo, J.P.; Gavara, R.; Hernández-Muñoz, P. Diffusion modeling in polymer-clay nanocomposites for food packaging applications through finite element analysis of TEM images. J. Membr. Sci. 2015, 482, 92-102. [CrossRef]

58. Momohjimoh, I.; Saheb, N.; Hussein, M.A.; Laoui, T.; Al-Aqeeli, N. Electrical conductivity of spark plasma sintered $\mathrm{Al}_{2} \mathrm{O}_{3}-\mathrm{SiC}$ and $\mathrm{Al}_{2} \mathrm{O}_{3}$-carbon nanotube nanocomposites. Ceram. Int. 2020, 46, 16008-16019. [CrossRef]

59. Vitta, Y.; Figueroa, M.; Calderon, M.; Ciangherotti, C. Synthesis of iron nanoparticles from aqueous extract of Eucalyptus robusta Sm and evaluation of antioxidant and antimicrobial activity. Mat. Sci. Energy Technol. 2019, 3, 97-103. [CrossRef]

60. Salton, M.R.J. Cell Membrane Transport: Principles and Techniques. J. Gen. Physiol. 1968, 52, 277-299.

61. Zaki, M.F.; Tawfik, S.M. Synthesis, surface properties and antimicrobial activity of some germanium nonionic surfactants. J. Oleo Sci. 2014, 63, 921-931. [CrossRef] 